\title{
Kepemimpinan Wanita Kristen: Suatu Sinergitas Antara Kesetaraan (Egalitarian) dengan Kemitraan (Partnership)
}

\author{
Danik Astuti Lumintang \\ Dosen Tetap Pascasarjana Sekolah Tinggi Teologi Abdi Allah
}

\begin{abstract}
The view that emphasizes the hierarchy and leadership of men is known as complementary. Complementary emphasizes that although men and women are equal before God. Men and women are created to fulfill different roles in relationships with one another. However, due to the advancement of civilization, and due to the awareness of the facts of social-political injustice against women, modern secular feminists (social-political) have emerged. This research reveals a synergy between equality and Christian women's leadership partnerships.
\end{abstract}

Keywords: Complementary; Egalitarianism, Partnership, Women

\begin{abstract}
Pandangan yang menekankan hirarkhi dan kepemim-pinan kaum laki-laki dikenal dengan sebutan complementary. Complementary menekankan bahwa walaupun laki-laki dan perempuan setara di hadapan Allah. Laki-laki dan perempuan diciptakan untuk memenuhi peran yang berbeda dalam hubungan satu dengan yang lain. Namun, karena kemajuan peradaban, dan karena kesadaran fakta ketidakadilan sosial-politik terhadap kaum wanita, bangkitlah modern secular feminist (social-politic). Penelitian ini mengungkap suatu sinegitas antara kesetaraan dengan kemitraan kepemimpinan wanita Kristen.
\end{abstract}

Kata Kunci: Komplementer; Egalitarianisme; Kemitraan; Perempuan 


\section{PENDAHULUAN}

Berabad-abad, orang Kristen di seluruh dunia telah dikuasai oleh cara berpikir hirarkhi laki-laki atas wanita bahwa laki-laki adalah pemimpin dan wanita dituntut untuk tunduk kepada suaminya berdasarkan Kejadian 1-3 dan Efesus 5:2223. Karena itu, selama berabad-abad kaum wanita dipenjarakan dengan keyakinan ini. Hal ini pun diungkapkan oleh Wayne Grudem: "For nineteen centuries Christians understood without confusion the plain words of Ephesian 5:22-24". ${ }^{1}$ Artinya selama Sembilan belas abad, gereja dikuasai oleh pandangan tradisional yang sangat menekankan kirarki laki-laki atas wanita.

Pandangan yang menekankan hirarkhi dan kepemim-pinan kaum laki-laki dikenal dengan sebutan tradisionalist ini, juga disebut complementary. Mereka menekankan bahwa walaupun laki-laki dan perempuan setara di hadapan Allah, mereka diciptakan untuk memenuhi peran yang berbeda dalam hubungan satu dengan yang lain. Mereka menekankan bahwa laki-laki ditentukan oleh Allah sebagai pemimpin dan perempuan tidak. $^{2}$

Dalam perkembangan selanjutnya, karena kemajuan peradaban, dan karena kesadaran fakta ketidakadilan sosial-politik

${ }^{1}$ Wayne Grudem, Biblical Foundations for Manhood and Womanhood, (Wheaton, Illinois: Crossway Books, 2002), p. 221 terhadap kaum wanita, bangkitlah modernt secular feminist (social-politik), dan demikian juga di kalangan perempuan Kristen mempersoalkan kekepalaan dan kepemim-pinan kaum laki-laki. Pada pertengahan abad ke-20 yang lalu bangkitlah liberal feminist secara khusus menaggapi pan-dangan tradisional (complimentarism). Mereka memper-juangkan kesamaan hak asasi kaum perempuan dengan mengubah paradigma laki-laki menjadi paradigm perempuan berdasarkan penafsiran ulang.

Selain mereka, dikalangan perempuan injili, bangkit pendekatan yang lain, jauh lebih lunak dari hermeneutika kaum feminist liberal dan secular.Mereka dikenal sebagai kaum egalitarian injili. Mereka percaya bahwa Alkitab mengenai kesederajatan atau kesejajaran antara wanita dan laki-laki, sehingga baik laki-laki maupun wanita sama-sama melakukan peran yang sama.

Pandangan egalitarian berimplikasi pada beberapa pernyataan kaum egalitarian berikut ini: (1). Tentu saya percaya bahwa Seorang istri semestinya tunduk kepada suaminya. Dan Seorang suami semestinya juga tunduk kepada istrinya.Atau (2). Aku akan tunduk kepada suamiku sejauh ia tunduk kepadaku. (3). Tidak ada perbedaan

${ }^{2}$ Shelly Cunningham, "Women, Leadership Role of", Evangelical Dictionary of Christian Ledearship, edited by Micheal J. Anthony, (Grand Rapids: Baker Academic, 2001), h. 723 
peran kepemim-pinan antara laki-laki dan wanita. Kalau kaum pria dapat memimpin, maka kaum wanita pun dapat pemimpin. Tidak ada peran kepemimpinan yang unik bagi suami. Karena baik istri maupun suami, keduanya saling menundukan diri satu dengan yang lain.

Persoalannya apakah dalam semua hal, kaum perempuan dapat melakukan apa yang dilakukan oleh kaum laki-laki? Atau sebaliknya, apakah semua yang dapat dilakukan oleh kaum laki-laki dapat dilakukan oleh kaum perempuan? Apakah kaum laki-laki dapat mengandung dan melahirkan sebagaimana kaum perempuan dapat lakukan? Apakah memang laki-laki adalah kepala rumah tangga? Apakah perempuan tidak.

\section{ANALISA DAN HASIL PEMBAHASAN}

\section{Egalitarianisme}

Kata egalitarianisme berasal dari bahasa Perancis "Egal" yang berarti "sama". Egalitarianisme adalah doktrin atau pandangan yang menyatakan bahwa manusia itu ditakdirkan sama sederajat. Dalam pengertian semua orang atau manusia adalah sama dalam status nilai atau moral secara fundamental. ${ }^{3}$
Argumentasi Egalitarian menurut

Kejadian 1-2

Ada beberapa argumentasi dari pandangan egalitarian terhadap Kejadian 1-2, yaitu: (1) Menekankan kesamaan kedudukan dan fungsi. Egalitarian memandang bahwa laki-laki dan perempuan memiliki kedudukan dan fungsi yang sama di mata hukum. Antara laki-laki dan perempuan tidak memiliki perbedaan, keduanya memiliki hak yang sama. hakuntuk hidup, hak untuk menentukan pendapat, dan lain-lain, karena segambar dengan Allah. (2) Menolak Hirarkhy. Hirarkhy adalah pendapat kaum Tradisional. Mereka berpendapat bahwa, manusia itu memiliki hirarkhi atau urutan. Biasanya terdapat 4 (empat) dasar hirarkhi, yaitu: (a) Karena Adam memberi nama kepada Hawa. Adam merupakan manusia pertama yang diciptakan Allah, maka Adamlah yang memberi nama kepada perempuan yang diciptakan sesudah Adam. Pandangan ini menjelaskan mengenai hirarkhial yang dahulu dan kemudian. Yang terdahulu memberi nama kepada yang kemudian. Adam memberi nama kepada perempuan yang diciptakan belakangan yaitu Hawa. (b) Kata "Adam" itu Hirarkhy (Kej. 1:26-27). Adam yaitu menunjuk pada sub atau titel (urutan) yang pertama.Urutan pertama dimana Adam diciptakan oleh Allah,
${ }^{3}$ Arneson Richard, Egalitarianisme, The Stanford Encyclopedia of Philosophi, (2002). 
bukan perempuan yang diciptakan pertama kali. (c) Laki-laki diciptakan lebih dahulu dari perempuan. Adam diciptakan Allah terlebih dahulu daripada perempuan.Penciptaan Adam adalah tindakan Allah secara langsung, sedangkan perempuan diciptakan Allah setelah Adam dicipta. Menurut pandangan tradisionalisme, hal ini menjelaskan bahwa penciptaan manusia pertama secara hirarkhi adalah lakilaki terlebih dahulu diciptakan, barulah perempuan diciptakan. Mereka memahami teks mengenai penciptaan manusia pertama adalah secara harafiah. (d) Perempuan diciptakan sebagai penolong, artinya perempuan adalah pelayan laki-laki. Perempuan menurut kelompok tradisional adalah kelas dua atau kelompok kedua, yaitu setelah lakilaki. Karena perempuan diciptakan dari tulang rusuk laki-laki (dari bagian tubuh lakilaki), maka secara hirarkhi perempuan adalah penolong atau pelayan bagi lakilaki.Perempuan memiliki tugas untuk menolong dan melayani laki-laki. ${ }^{4}$

Keempat hirarkhi ini ditolak oleh kaum Egalitarian, disebabkan oleh karena argumentasi mereka sebagai berikut: (1) Karena adanya kesamaan laki-laki dan perempuan, bahwa keduanya diciptakan oleh Allah (Kej. 1-2). (2) Manusia, baik laki-

${ }^{4}$ Linda L. Belleville, Women in Ministry: An Egalitarian Perspektive: (Zondervan, Grand Rapids: by james R. Beck, 2005), p. 28-30 laki maupun perempuan keduanya diciptakan oleh Allah menurut gambar-Nya. Hal ini menjelaskan, bahwa manusia baik laki-laki maupun perempuan memiliki gambar yang sakral dari Allah. Manusia sebagai makhluk yang diberi kapasitas secara unik oleh Allah, yang bertujuan untuk mencerminkan dan merefleksikan karakter Allah. ${ }^{5}$ (3) Kesamaan fungsi atau tugas yaitu: baik laki-laki maupun perempuan ditugaskan untuk menguasai dunia (Kej. 1:26-28). Kesamaan fungsi dan tugas baik lakilaki maupun perempuan juga adalah didasarkan secara khusus pada ayat 27, "Allah menciptakan manusia menurut gambar-Nya". Berarti umat manusia, baik laki-laki maupun perempuan diciptakan menurut gambar Allah. Gambar Allah itu menjelaskan mengenai panggilan terhadap manusia untuk memerintah dan menguasai dunia ini. Manusia baik laki-laki maupun perempuan dipanggil sebagi duta Allah untuk menahklukan, memenuhi dan memelihara bumi ini. Dalam hal ini, manusia dipanggil untuk merefleksikan karakter Allah yang memerintah alam semesta ini berdasarkan kebenaran-Nya. Salah satu contoh kesamaan fungsi dalam keluarga adalah tanggung jawab melahirkan dan membersarkan anakanak. $^{6}$ (4). Perempuan diciptakan sebagai

${ }^{5}$ R.C. Sproul, Kebenaran-Kebenaran Dasar Iman Kristen, (Malang: Seminari Alkitab Asia Tenggara, 2005), h. 171.

${ }^{6}$ Ibid., h. 172. 
Penolong laki-laki, tidak baik laki-laki sendirian. Ini tidak bicara sub-hirarkhi atau urutan, karena laki-laki diciptakan Allah lebih dahulu daripada perempuan. Justru hal ini berbicara tentang perempuan sebagai subyek penolong. Allah menyatakan dalam Kejadian 2:18: "Tidak baik manusia itu seorang diri. Aku akan menjadi-kan seorang penolong baginya."

Teks ini menyatakan bahwa tidak baik kalau laki-laki sendirian (tidak menikah dengan perempuan). Laki-laki tanpa perempuan, itu adalah bagaikan masakan tanpa garam, hambar. Wanita diciptakan untuk menolong laki-laki.Bukan menjadi perongrong laki-laki. Perempuan atau istri adalah asisten laki-laki atau suami, yang mengisi kekurangannya dan mengganti atau mewakili bila diperlukan. Penolong berarti mengangkat, menyelamatkan, memberi jalan keluar, menghi-bur dan bukan menjatuhkan atau mengkritik serta membuat-nya malu. Perempuan sebagai penolong laki-laki atau pasangan hidupnya, sesuai dengan panggilan Allah. $^{7}$

\section{Perempuan dalam Kepemimpinan}

Pada umumnya orang mengetahui bahwa nabi, rasul, guru, penginjil adalah kaum laki-laki, sehingga kelompok

\footnotetext{
${ }^{7}$ Danik Astuti Lumintang, Pak Keluarga; Diktat kuliah S.Pd.K I-3, (2010), h. 10.

${ }^{8}$ Bernadette J. Brooten, Women Leaders in the Ancient Synagogue: Inscriptional Evidence and
}

tradisional percaya bahwa yang patut melayani di gereja adalah mereka yang bergender laki-laki. Tetapi dalam Alkitab, kita menemukan beberapa perempuan yang melayani: (1) Maria saudara perempuan Musa, disebut nabiah (Kel. 15:20, Mik. 6:4). (2) Debora disebut nabi (Hak. 4:4), sebagai hakim (Hak. 4-5), dan ibunya Israel (Hak. 5:7). Arti Israel menurut Brooten, adalah gelar yang diberikan untuk pemimpin umat, termasuk gelar atau jabatan di Sinagoge dalam kumunitas Yahudi. ${ }^{8}$

Disamping Maria dan Debora, Allah juga menyampai-kan melalui nubuat Yesaya mengenai peran perempuan (Yes. 8:3), termasuk peran Huldah (2 Raj. 20:14, Zef.1:1; Nah. 3:8-10, Hab. 1:6). Salah satu tugas perempuan dalam Perjanjian Lama adalah melayani di pintu masuk kemah suci Tabernakel (Kel. 38:8; I Sam. 2:22). Begitu pula dalam Perjajian Baru, banyak perempuan yang terlibat dalam pekerjaan Tuhan:

Women are singled out in the early
church as apostles (Rom. 16:6),
prophets (act. 21:9; I Cor. 11:5),
evangelists (Phil. 4:2-3), patrons (Rom.
16:2), teachers (Act. 18:24-26; Titus
2:3-5), deacons (Rom. 16:1; I Tim.
3:11), prayer leaders (I Cor. 11:15),
overseers of house shurches (Act.
12:12; 16:14-15; Col. 4:15), prayer
warriors (1 Tim. 5:5), and those who

Background Issues, (Chico, Calif: Scholars Press, 1982), p. 83-90 
were know for their mercy and hospitality (5:10). ${ }^{9}$

Secara khusus, Febe mendampingi pelayanan Paulus (Roma 16:1-2 uraikan) dalam tugas misi dan pelayanan para rasul. Dalam pelayanan Paulus sebagai rasul, melibatkan banyak perempuan sebagai teman rasul yang disebut co-worker, seperti Triphena dan Triphosa dan Persis (Roma 16:3-4; Fil. 4:3). Perempuan secara sederajat disebut sebagai co-worker. Juga dalam Alkitab beberapa perempuan berperan sebagai diaken dalam gereja, yang memenuhi keperluan-keperluan jasmani orang percaya. Febe adalah salah satu diaken (1 Kor. 16:1518; 2 Kor. 8:18-24; Fil. 2:19-30). ${ }^{10}$

Priskila dan Akwila yang terlibat dalam pelayanan pararasul (Kis. 18:1-3). Mereka ini perempuan-perempuan bukan rasul, sama dengan Silas, Timotius, Titus, bukan rasul, namun mereka terlibat dalam pelayanan rasul, pelayanan dalam pertumbuhan gereja (I Kor. 9:5-6; 2 Kor. 8:16-21; I Tes. 2:7-9). ${ }^{11}$ Perempuan tua dalam gereja diharapkan mengajar perempuan muda dalam gereja (Tit. 2:3-5). Hal ini menjelaskan mengenai ruang

${ }^{9}$ Linda L. Belleville, Two Views onWomen in Ministry: An Egalitarian Perspektive, Linda L. Belleville..., p. 36

${ }^{10}$ Linda L. Belleville, A Letter of Apologetic Self-Commendation: 2 Cor. 1:8-7:16, (NovT 31 (1989), p. 142-64; Linda L. Belleville,Two Views on Women in Ministry: An Egalitarian Perspektive, Linda L. Belleville. 47

${ }^{11}$ Some tradisionalists question the female gender of Greek name Iounian in Romans 16:7. Yet mengajar dalam gereja bagi perempuanperempuan. Sekalipun tidak ada rasul perempuan dari 12 rasul yang ada, namun banyak perempuan yang menyertai pelayanan para rasul dan banyak perempuan yang terlibat dalam kepemimpinan gereja setelah para rasul. Mereka tidak hanya menyertai, tetapi mereka menjadi pemimpin gereja-gereja di Asia Kecil, Yunani dan Kreta. $^{12}$

\section{Komplimentari}

Komplimentari injili dibedakan dengan komplimentari klasik. Komplimentari klasik di kenal dengan pandangan tradisional mengenai kedudukan dan peran laki-laki dan perempuan. Pandangan komplimentari klasik (tradisional) sangat patriarch hiharkhi. Tentu penulis sendiri tidak menemukan dasar theologis untuk mengikuti atau mendu-kung pandangan yang demikian (pandangan komplimentari klasik atau tradisional). Karena itu, yang lebih dekat dengan pemahaman dan keyakinan penulis dengan

there is not reason to read Ionian in any way but feminine. Linda L. Belleville, Two Views on Women in Ministry: An Egalitarian Perspektive, Linda L. Belleville ..., p. 39

${ }^{12}$ Dorothy Irvin, The Ministry of Women in the Early Church, " Duke Divinity Scholl Review (1980), 76-86; Linda L. Belleville, Women Leaders and the Church..., p. 21-31. 
Alkitab adalah Pandangan Egalitarian Injili dan komplimentari Injili.

Kalau komplimentari klasik (tradisional) memenjarakan perempuan dalam gereja dengan jeruji hermeneutika patriark dan juga hermeneutika hirarkhi, maka kaum feminisme kontemporer (secular feminism) membebaskan wanita secara total (tanpa batas sama sekali). Kalau egalitarian injili menegaskan peran perempuan tidak berbeda dengan peran laki-laki, karena kesamaan dan kesederajatan gender, maka kaum komplimentari Injili menegaskan persamaan dan perbedaan yang menuntut adanya saling melengkapi antara satu dengan yang lainnya. Saling melengkapi adalah tema besar para penganut pandangan ini.

Kepemimpinan Perempuan dalam Perjanjian Lama

Adam memberi nama kepada istrinya Hawa. Hal ini menjelaskan mengenai pengertian sub-ordinate (bawahan), namun pemberian nama ini terjadi sebelum Adam dan Hawa jatuh dalam dosa (Kej. 2:18-20). (1) Manusia (Adam) diberikan otoritas memberi nama kepada binatang-binatang. (2) Dan Tuhan menciptakan perampuan dari tulang rusuk Adam. (3) Adam menyebut namanya "perempuan" (pada umumnya). Tiga hal ini menjelaskan tentang perbedaan

\footnotetext{
${ }^{13}$ Linda L. Belleville, Women Leaders and the Church..., p. 130
}

peran yang menjadi dasar untuk mengakui adanya kekepalaan dan ketundukkan dalam konteks hubungan laki-laki dan perempuan yang belum berdosa. Sehingga kesatuan yang ada antara Adam dan Hawa bukanlah yang lebih tinggi dan lebih rendah.Ketundukkan yang lebih rendah ke yang lebih tinggi, melainkan hubungan yang tanpa dosa.Adam dan Hawa menjadi satu daging (Kej. 2:24-25; Mat. 10:7-8). ${ }^{13}$

Peristiwa kejatuhan Adam dan Hawa dalam kejadian 3 telah berbeda dengan kejadian 2, maka hubungan Adam dan Hawa pun sudah diganggu oleh dosa.Demikian pula peranan Adam sebagai laki-laki dan suami dengan Hawa sebagai perempuan dan istri pun telah terganggu. Karena itu,tidaklah dapat menerapkan arti memberi nama dan mengambil dari tulang rusuk sebagai alasan untuk mendukung komplimentari klasik (tradisional) yang menjunjung tinggi kedudukan dan peran laki-laki. Kendatipun demikian, secara harafiah dalam konteks suami-istri tidak mungkin kedua-duanya sebagai pemimpin, kecuali dalam konteks keluarga di mata anak-anak keduannya berperan sebagai pemimpin di mata anakanak. Seperti Adam dan Hawa di mata anakanak mereka, Kain dan habil.Tidak dapat dipungkiri bahwa dalam Perjanjian Lama porsi pemimpin dan kepemimpinan 
senantiasa berhubungan dengan kaum lakilaki.

Para patriarch: Abraham, Isak, Yakub dan Yusuf adalah orang-orang yang dipilih dan dipakai Tuhan dalam kepemimpinan. Kendatipun demikian ada sedikit ruang bagi peran dan kepemimpinan bagi kaum perempuan, seperti Sarah, Ribkah yang berperan saling melengkapi. Sarah melengkapi kepemimpinan Abraham, Ripka melengkapi kepemimpinan Yakub. Saling mengisi diantara kedua pasangan, Ribka mengisi dan melengkapi kepemimpinan Isak.Memang tidak Nampak Sarah dan Ribka sebagai pemimpin dalam konteks umat Allah.

Khususnya kepemimpinan mereka dalam dan di tempat umum, namun mereka sangat berperan terhadap kepemimpinan suami mereka yang memimpin umat. Belleville menyatakan demikian: "Beyon this one office, however, there do not appear to be any other restrictions on women in public leadership in ancient Israel. While they often remain the exception, women did at one time or another play every other significant role." ${ }^{14}$ Namun secara eksplisit perempuan yang tampil sebagai pemimpin umat adalah Debora.

Debora adalah hakim dan kepemimpinannya berlang-sung sebelum

\footnotetext{
${ }^{14}$ Ibid., p. 133-134; Carrol D. Osburn (Ed.), See also the Contributions to Essays on Women in
}

kerajaan Israel dimulai. Sebagai hakim, Debora ikut maju dalam berperang. Dia menjadi representatip Allah untuk menyampaikan apa yang akan terjadi dalam peperangan melawan kedesi (Hak. 4). Kepemimpinan perempuan dalam Perjanjian Lama juga Nampak melalui Meriam seorang nabiah (Kel. 15:20-21) dan Huldah (2 Raj. 22:11-20).

Nabi-nabi dalam Perjanjian Lama adalah pemimpin. Mereka diutus oleh Allah menjadi representatif kepemimpinan Allah. Selain mereka, Ester juga adalah pemimpin perempuan yang sangat berperan besar dalam menentukan nasib umat Allah.(Est. 4:11-17). Selain Esther ada seorang perempuan bijak yang juga terlibat dalam kepemimpinan, yaitu seorang dari Tekoa, yang melayani sebagai penasehat raja Daud (2 Sam. 14). Begitu juga dengan wanita bijak lainnya yang bernama Abel Beth Maacah. Dalam hubungannya dengan Ayub (Ay. 20:14-22).

Kepemimpinan para nabi dan imam dalam Perjanjian Lama haruslah dipahami dalam satu konteks New Covenant (Perjanjian Baru). Secara khusus Blomberg membahas mengenai kepemimpinan para nabi, para imam: (1) Perempuan adalah pribadi seutuhnya, diciptakan sesuai gambar Allah sebagaimana laki-laki. (2) Tidak ada hubungan atau kesesuaian antara peran para

Earliest Christianity, (Joplin, MO.: College Press, 1993-1995), p. 1:25-39; 2. 37-153. 
imam Israel dan peran pendeta pada masa ini. Karena Kristus adalah Iman Agung yang menjadi perantara kita dengan Allah. Dan Ia menjadi jalan masuk kepada Allah (I Pet. 2:5). (3) Tidak satupun wanita dalam Perjanjian Lama terlibat dalam kepemimpinan rohani sebagai imam. (4) Tidak dapat disangsikan bahwa kepemimpinan patriack dicatat dalam konteks dosa manusia dan konsekuensinya, sebagai contoh dari kepemimpinan kaum laki-laki di dunia yang telah berdosa. Dan hal ini menjadi contoh bagi perempuan untuk terlibat dalam kepemimpinan di setiap arena.

(5) Kepemimpinan kaum laki-laki yang menonjol dalam Perjanjian Lama bukanlah bersifat tertutup pada berakhirnya kitab Perjanjian Lama, karena kepemimpinan wanita mulai nampak pada Perjanjian Baru. ${ }^{15}$

Memahami laki-laki dan perempuan dalam Alkitab perlu juga mengetahui pandangan Yahudi pada era intertestamental (masa antara PL-PB). Perempuan senantiasa dilihat sebagai seorang yang menyediakan apapun yang diperlukan laki-laki, yang menyiapkan kesediaan rumah, menemani suami-suami mereka, menghindari kontak dengan pria lain, menggunakan kecantikan mereka untuk membuat suami mereka lebih

${ }^{15}$ Linda L. Belleville, Two Views on Women in Ministry; Women Ministry: A Complementarian Perspective, Craig L. Blomberg,...,p. ${ }^{137-138}$. senang. Dan perempuan dilihat sebagai sumber kejahatan. ${ }^{16}$

Pada abad I perempuan YunaniRomawi mendapat posisi yang lebih baik. Khususnya pada waktu filsuf Sokrates dan Plato menjamin kesetaraan laki-laki dan perempuan dalam filosofi mereka.Yang memengaruhi literature-literatur Yahudi pada masa intertestamental.Karena itu, kemudian perempuan Romawi, dijamin kebebebasannya secara legak. Walaupun masih ada kelompok lain yang mengikuti gaya hidup Barbarian yang merendahkan hidup kaum perempuan, yang melihat suami atau laki-laki berhak menghukum istri dan anak-anak, perempuan seperti barang dagangan dan yang berhak menghukum perempuan. Namun kebiasaan ini kemudian berubah setelah Injil secara perlahan mendapat tempat di Eropa.

\section{Kepemimpinan Perempuan dalam Perjanjian Baru}

Matius menampilkan lima perempuan dalam silsilah (Mat. 1:1-15), yaitu Tamar, Rahab, Rut, Bethzeba dan Maria ibu Yesus. Blomberg menjelaskan hal ini bahwa, Yesus datang untuk semua orang termasuk yang di marjinalkan oleh orang Yahudi, yaitu perempuan. $^{17}$ Lukas

${ }^{16}$ Ibid., p. 139; Talllan, Jewish Women in Greco-Roman Palestine, (Peabody, Mass: Hendrickson, 1996), 226

${ }^{17}$ Linda L. Belleville, Women in Ministry..., p. 141; Craig L. Blomberg, The liberation of Illegitimacy: 
menampilkan secara jelas peran perempuan pada awal kitabnya yakni Elizabeth dan Maria dalam konteks kelahiran Tuhan Yesus Kristus. Lukas juga menampilkan pelayanan Tuhan Yesus yang bersama sejumlah perempuan seperti, ibu mertua Simon Petrus yang menghentikan pendarahan seorang perempuan (Luk. 5:25-34), membangkitkan dari kematian anak Zairus. Lukas juga mencatat mengenai Maria dan Marta waktu Tuhan Yesus berada di Bethani. Begitu pula dengan Injil-Injil yang lain, Markus dan Yohanes. Dalam Kisah Para Rasul dicatat bahwa perempuan-perempuan juga menerima Roh dan bernubuat sama seperti laki-laki (Kis. 2:17-18). Perempuan juga berperan besar dalam gerakan kekristenan mula-mula. Seperti Dorkas atau Tabita yang menolong banyak orang miskin, Lidya membantu perjalanan misi Paulus termasuk Priskila dan Akwila. Nama Priskila muncul 4 kali dalam Perjanjian Baru (Kis. 18:18, 26; Rom. 16:3; 2 Tim. 4:19).

\section{$\underline{\text { Pembahasan Teks-Teks Injil dalam }}$}

\section{Tulisan Paulus}

Ada beberapa teks-teks dalam Perjanjian Baru, khususnya dalam tulisan Paulus yang menimbulkan salah pengertian mengenai kedudukan perempuan dalam gereja atau dalam jemaat. Teks-teks tersebut

Women and Rulers in Matthew 1-2, (BTB 21 (1991), p. $145-50$ dianggap teks kontraversial yang menyebabkan minimal dua pendapat yang bertentangan satu dengan yang lain.

\section{Galatia 3:28}

Dalam Teks ini, tetulis tidak ada lagi orang Yahudi maupun Yunani, hamba atau orang merdeka, laki-laki atau perempuan, karena engkau semua adalah satu dalam Kristus. Sesungguhnya Paulus menjelaskan tidak adanya diskriminasi bagi orang yang percaya Tuhan Yesus Kristus. Kelompok lain menilai Paulus tidak konsisten dalam hal ini. Khususnya perbedaan peran antar gender dalam gereja. Satu sisi nampak kesetaraan (Gal. 3:26-29). Tidak ada keperbedaan di Injil-Injil dan surat-surat Paulus. Paulus melihat orang-orang Yahudi dan Yunani tetapi tidak membedakan, termasuk tidak membeda-bedakan peran.

\section{Korintus 11:2-16}

Kata kunci penganut komplimentari mengenai 1 Korintus 11:2-6, bahwa laki-laki dan perempuan saling melengkapi, saling mengisi ada pada tulisan Paulus. Persoalan mengenai perempuan dalam teks ini dikemukakan oleh Paulus, diantaranya ada 6 hal, yaitu: (1) Kepala dari perempuan adalah laki-laki (ay. 3b). (2) Perempuan yang berdoa dan bernubuat dengan kepala yang tidak 
bertudung, ia menghina suaminya yang adalah kepalanya (ay. 5). (3) Perempuan yang tidak mau menudungi kepalanya, maka haruslah ia juga menggunting rambutnya. Karena bagi perempuan adalah suatu penghinaan, jika rambutnya digunting atau dicukur. Oleh karena itu, perempuan haruslah menudungi kepalanya. Sehingga ia menyinarkan kemuliaan laki-laki (ay. 6, 7b).

(4) Perempuan berasal dari laki-laki (ay. 8b).

(5) Perempuan diciptakan karena laki-laki (ay. 9b). (6) Kehormatan bagi perempuan, jika ia berambut panjang, sebab rambut diberikan kepada perempuan untuk menjadi penudung (ay. 15).Semua hal yang berkenaan dengan perempuan di atas dibicarakan oleh Paulus dalam ibadah Kristen.

Mengenai kepala perempuan adalah laki-laki, yang dipahami oleh kelompok Complimentary Clasik (Tradisional) sebagai otoritas dan oleh Egalitarian bukan Hirarkhy tetapi sebagai sumber. Kita menemukan urutan laki-laki-Kristus, perempuan-lakilaki, Kristus-Allah. Setelah urutan ini, Paulus memberikan instruksi kepada laki-laki dan perempuan, bahwa: "Kepala dari tiap lakilaki adalah Kristus", dan "Kepala dari perempuan adalah laki-laki”. Dalam hal ini, Kristus adalah Kepala yang kepadanya baik perempuan maupun laki-laki tunduk. Setelah ini ada instruksi yang sama, yaitu: (1). Lakilaki yang berdoa atau bernubuat dengan kepala bertudung menghina kepalanya; (2). Perempuan yang berdoa atau bernubuat dengan kepala yang tidak bertudung menghina kepalanya.

Dalam hal ini, tidak menjelaskan hirarkhi (tidak ada unsur hirarkhi), melainkan mengenai hubungan. Mengenai menudungi kepala (ay. 4-5), tidak dilatarbelakangi oleh fenomena budaya. Para imam Romawi menutup kepala mereka pada waktu melakukan tugas seremoni ibadah kepada berhala: (1). Laki-laki Yunani berambut panjang sampai ke bahu menerangkan sebagai homo seksualitas. (2). Rambut pendek bagi perempuan Yunani, menjelaskan tentang lesbian.Jadi Paulus menyuruh untuk perempuan menggunakan tudung kepala dan laki-laki tidak menggunakan tudung, tidak menjelaskan perbedaan laki-laki dan perempuan. Melainkan menjelaskan mengenai perbedaan ibadah Kristen dan non Kristen. Ibadah Kristen harus berbeda dengan ibadah dengan ibadah untuk para berhala. Paulus memaksudkan bahwa laki-laki dan perempuan Kristen pada waktu beribadah, tidak menampakkan ketidak setiaan mereka kepada Allah.Selain itu, menjelaskan mengenai kekudusan bahwa, baik laki-laki maupun perempuan harus hidup kudus, bukan lesbian dan bukan homo seksual.

Dalam ayat $7 \mathrm{~b}$ Paulus menjelaskan bahwa: ...’laki-laki menyinarkan gambaran 
dan kemuliaan Allah, tetapi perem-puan menyinarkan kemuliaan laki-laki”. Teks ini tidak membahas mengenai hirarkhi bahwa, laki-laki itu adalah gambaran kemuliaan Allah dan perempuan adalah gambaran kemuliaan laki-laki.Ayat ini sering disalahgunakan untuk ketundukan perempuan terhadap laki-laki, seperti halnya bahwa Hawa dibuat dari Adam, maka Hawa tidak diciptakan menurut gambar Allah. Pendapat seperti ini menyatakan penghayatan kepada Allah, sebagaimana dijelaskan oleh Blomberg: “Rakotoharintsifa (Conflits a Corinthe, 219-20) stresses that the notion that the man is not fully honoured without the women's glory also guards against the view that does not ascribe equal dignity to the women." 18

Dalam ayat 8-9 tertulis: "Sebab lakilaki tidak berasal dari perempuan, tetapi perempuan berasal dari laki-laki. Dan lakilaki tidak diciptakan karena perempuan, tetapi perempuan diciptakan karena lakilaki.'Kalimat ini dianggap sebagai penegasan hirarkhi. Persoalan ayat 8-9 ini disimpulkan juga oleh Paulus dalam ayat 11: “...dalam Tuhan tidak ada perem-puan tanpa laki-laki dan tidak ada laki-laki tanpa perempuan."

Pada ayat 10: perempuan harus diberikan tanda. Dalam hal ini ayat 8-9

${ }^{18}$ Linda L. Belleville, Women in Ministry; $A$ Complementarian Perspective, ${ }^{\text {Craig }} \mathrm{L}$. Blomberg, (BTB 21 (1991), p. 159 bukanlah hirarkhi, karena ayat 10 menjelaskan mengenai perempuan adalah wibawa laki-laki. Dimana perempuan mendapatkan tanda ini mengenai dirinya sendiri, bahwa perempuan memiliki kemampuan untuk memelihara dirinya. Sedangkan pada ayat 11, Paulus menyimpulkan mengenai perempuan dan laki-laki adalah "saling melengkapi".

\section{Timotius 2:8-12}

Dalam teks ini menuliskan beberapa hal mengenai peran perempuan, diantaranya yaitu: (1) Perempuan hendaknya berdandan dengan pantas, dengan sopan dan sederhana, rambutnya jangan berkepangkepang, jangan memakai emas atau mutiara ataupun pakaian yang mahal-mahal; (2) Hendaklah perempuan berdandan dengan perbuatan baik, seperti yang layak bagi perempuan yang beribadah; (3) Seharusnya perempuan berdiam diri dan menerima ajaran dengan patuh; (4) Perempuan tidak diijinkan mengajar dan juga tidak diijinkan memerintah laki-laki, hendaknya perempuan berdiam diri.

Paulus dalam hal ini mendorong Timotius untuk berdiri teguh dalam menghadapi pengajaran sesat di Efesus. Maka itu untuk memahami I Tim. 2:8-12, 
harus dipahami dalam terang Firman Tuhan terhadap bahaya paham atau heresy terhadap gereja. Perintah atau instruksi pada perempuan untuk belajar dalam ketenangan dan ketundukan dalam teks ini, dalam pengertian perempuan didorong untuk belajar Firman Allah sebagaimana laki-laki. Sesungguhnya kata "berdiam" diartikan supaya perempuan dapat kooperatif, dapat bekerjasama dan penuh dengan ketundukan.Hal itu bukan hanya dituntut pada perempuan, melainkan juga kepada laki-laki yang percaya. Paulus bukan melarang semua bentuk mengajar dalam gereja, namun Paulus menjelaskan dalam konteks ini berhubungan dengan kriteria pelayanan gereja yang disebut dengan pengawas dan diaken (I Tim 3:1-12).

\section{Korintus 14:33-38}

Mengenai maksud Paulus menyuruh perempuan berdiam diri, tidak boleh bicara dalam konteks jemaat haruslah dipahami dalam terang ayat 36. Ada perempuanperempuan yang berotoritas, berwibawa dan Paulus meminta mereka diam dan Paulus bertanya apakah Firman itu berasal dari dirimu? Paulus menantang kelompok konservatif yang tekun, yang legalistik, sehingga seolah-olah mereka yang lebih berwibawa daripada Firman Tuhan. Perempuan-perempuan disuruh berdiam diri, karena bagi Paulus adalah sangat penting untuk belajar sebelum melayani. Karena dalam kenyataanya juga pada zaman Paulus, perempuan-perempuan kurang dalam pendidikan. Oleh karena itu Paulus memerintahkan untuk berdiam diri, sebaliknya belajar Firman Tuhan.

Dari semua uraian yang dikemukakan di atas, kaum egalitarian menegaskan terhadap kaum tradisional yang menyerang mereka terhadap Alkitab, diantaranya yaitu kitab Korintus, Titus dan Efesus. (1) Mereka menjelaskan sejarah dan konteks bagi kitab Korintus adalah berkenaan dengan kasus perempuan mengganggu pelayanan di gereja melalui bertanya mengenai suami mereka di saat ibadah berlangsung. Karena itu Paulus menyuruh mereka diam, tidak boleh berbicara. (2) Perempuan tidak boleh mengajar, karena konteks perempuan diwaktu itu mereka adalah perempuan pengkhotbah untuk agama non Kristen. Mereka berpendapat bahwa mereka yang melahirkan, maka mereka menganggap lebih unggul dari laki-laki. (3) Perihal mengenai "kepala" dalam kitab Efesus, menjelaskan mengenai peranan dalam keluarga. Namun yang utama adalah bukan kepala gereja.Hanya Kristuslah yang kepala gereja 
yang memegang posisi pemimpin dalam gereja. $^{19}$

\section{$\underline{\text { Sinergitas Kepemimpinan Wanita dan }}$}

\section{Laki-Laki}

Shelly Cunningham menjelaskan mengenai sinergitas peran kepemimpinan perempuan dan laki-laki sebagai berikut: (1). Dalam Alkitab, perempuan berperan sebagai pemimpin non-formal (non-jabatan), sedangkan laki-laki berperan sebagai pemimpin formal (jabatan). Contoh: Sarah (Kej. 21:12); Abigail (1 Sam. 25:1-35); Elizabeth dan Maria (Luk. 1-2). Pengaruh mereka besar sebagai partner pemimpin lakilaki. (2). Alkitab perempuan juga berperan sebagai pemimpin formal (jabatan). Contoh: Debora adalah seorang hakim; Mariam adalah seorang nabiah dan Ester adalah seorang nabiah. Mereka ini adalah pemimpin formal yang berpen-garuh besar sebagai partner laki-laki. ${ }^{20}$

Sinergitas kepemimpinan wanita antara egalitarian dan complimentari berdasakan Alkitab, adalah sebagai berikut:

Pertama, dalam keluarga: Yang dapat dipegang dari realita perempuan sama dengan laki-laki sebagai mahkluk yang diciptaan oleh Allah, segambar, senilai, sama

\footnotetext{
${ }^{19}$ LaVerne A. Tolbert, "Women, Ordinations of", Evangelical Dictionary of Christian Education, Micheal J. Anthony (Ed.), (Grands Rapids, Michigan: Baker Academic, 2001), p. 724.

${ }^{20}$ Shelly Cunningham' "Women Leadershif Role of" Evangelical Dictionary of Christian
}

harganya yaitu darah Yesus (tebusan). Perempuan dan laki-laki berbeda dalam beberapa hal. Perbedaan fisik, psikis (jiwa), namun keperbedaan ini menuntut saling melengkapi atau saling mengisi. Bukan saling mengungguli. Memang suami-istri berbeda, namun disatukan dalam pernikahan, itu artinya masing-masing keperbedaan ini disatukan. Bukan keperbedaannya dihilangkan, tetapi disatukan dalam pengertian saling melengkapi (Complimentary), saling mengisi, saling menguat-kan, termasuk saling mengasihi dan saling tunduk.

Kedua, dalam Gereja: Perbedaan lakilaki dan perempuan tidak mendapatkan tempat (dalam keluarga ada). Karena itu, baik laki-laki maupun perempuan keduaduanya mempunyai hak yang sama sebagai orang percaya, yang berdiri dihadapan Allah Tritunggal maupun sebagai anggota tubuh Kristus. Mereka sama-sama memiliki hak sama-sama diselamatkan dalam Tuhan Yesus Kristus, tidak ada yang unggul.

Ketiga, dalam Pelayanan: Baik laki-laki maupun perem-puan, kedua-duanya dipanggil Allah melayani untuk menjadi hamba Allah, menjadi utusan-Nya. Karena itu kepada mereka baik laki-laki maupun perempuan diberi karunia Roh Kudus yang

Education.... .... Micheal J. Anthony (Ed.), Evangelical Dictionary of Christian Education..., p. 722 
sama. Tidak ada karunia-karunia tertentu hanya untuk laki-laki dan karunia-karunia tertentu untuk perempuan. Baik laki-laki maupun perempuan akan menghadap tahta pengadilan Yesus Kristus. Pengadilan tidak berdasarkan gen-der (jenis kelamin), tetapi berdasarkan percaya dan tidak percaya, bertanggung jawab dan tidak bertanggung jawab, itu namanya partnershif atau mitra.

Keempat, tanggung jawab warga gereja dalam masyarakat: Menurut Alkitab tidak hanya bergender laki-laki tetapi perempuan juga. Laki-laki dan perempuan sebagai utusan Kristus dalam masyarakat. Laki-laki maupun perempuan sebagai garam dan terang dunia. Bukan hanya laki-laki atau juga bukan hanya perempuan. ${ }^{21}$

\section{KESIMPULAN}

Dari uraian di atas, maka dapatlah ditarik kesimpulan bahwa kedudukan lakilaki dan wanita adalah sama; peran laki-laki dan wanita adalah berbeda hanya berkenaan dengan fungsi alat kelamin, sedangkan berkenaan dengan tanggung jawab sebagai manusia, tidak ada perbedaan. Karena itu ditegaskan bahwa: (1). Tidak ada perbedaan theologis yang dijadikan alasan untuk membedakan kedudukan laki-laki dengan wanita di mata Allah dan di mata sesama manusia. (2). Perbedaan laki-laki dan perempuan adalah perbedaan sebagian peran sesuai dengan jenis kelamin dan kecenderungan berpikir, dan semuanya menegaskan adanya tuntutan untuk saling melengkapi satu dengan yang lain. (3). Tidak ada perbedaan peran laki-laki dan perempuan dalam gereja. Tidak ada dasar theologis untuk membatasi peran laki-laki dan perempuan dalam gereja termasuk dalam kepemimpinan. (4). Tidak ada perbedaan peran antara laki-laki dan perempuan dalam gereja, termasuk tidak ada perbedaan peran dan tanggung-jawab dalam kepemimpinan.

Kesimpulan di atas dibangun di atas pemahaman dan keyakinan Kristen bahwa baik laki-laki maupun wanita Kristen menerima anugerah yang sama, juru selamat yang sama, keselamatan yang sama, pengampunan yang sama. Juga baik laki-laki maupun perempuan menerima Alkitab atau firman Allah yang sama. Selain itu baik lakilaki maupun perempuan menerima Tuhan Yesus yang sama dan diselamat-kan dan pada saat yang sama menerima Roh Kudus sebagai meterai penebusan. Karunia Roh Kudus yang memperlengkapi orang percaya, tidak diberikan hanya untuk gender laki-laki, melainkan juga untuk gender wanita, 
termasuk karunia-karunia untuk perempuan sebagai pemimpin dalam gereja.

\section{DAFTAR PUSTAKA}

Belleville, Linda L. Women in Ministry: An Egalitarian Perspektive: Zondervan, Grand Rapids: James R. Beck, 2005

Belleville Linda L., A Letter of Apologetic Self-Commendation: 2 Cor. 1:8-7:16, (Nov. T 31 (1989)

Blomberg Craig L., The liberation of Illegitimacy: Women and Rulers in Matthew 1-2. BTB 21 (1991

Brooten Bernadette J., Women Leaders in the Ancient Synagogue: Inscriptional Evidence and Background Issues, Chico, Calif: Scholars Press, 1982

Cunningham Shelly, "Women, Leadership Role of", Evangelical Dictionary of Christian Ledearship, edited by

Micheal J. Anthony. Grand Rapids: Baker Academic, 2001

Ferguson Sinclair B., David F. wright, New Dictionary of Theology. Leicester, England: Inter-Versity Press, 1988

Grudem Wayne, Biblical Foundations for Manhood and Womanhood. Wheaton, Illinois: Crossway Books, 2002

Irvin Dorothy, The Ministry of Women in the Early Church," Duke Divinity Scholl Review, 1980

Lumintang Danik Astuti, PAK Keluarga; Diktat kuliah, Batu: Institut Injil Indonesia, Program S.Pd.K, 2010.

Osburn Carrol D. (Ed.), See also the Contributions to Essays on Women in Earliest Christianity. Joplin, MO.: College Press, 1995

Richard Arneson, Egalitarianisme, The Stanford Encyclopedia of Philosophi, (2002).

Sproul R.C., Kebenaran-Kebenaran Dasar Iman Kristen. Malang: Seminari Alkitab Asia Tenggara, 2005

Talllan, Jewish Women in Greco-Roman Palestine. Peabody, Mass: Hendrickson, 1996
Tolbert LaVerne A., "Women, Ordinations of", Evangelical Dictionary of Christian Education, Micheal J. Anthony (Ed.). Grands Rapids, Michigan: Baker Academic, 2001 